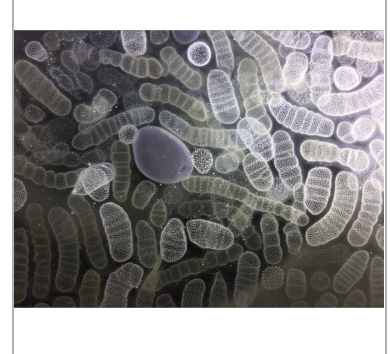

JUN 15, 2020

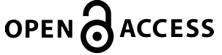

DOI:

dx.doi.org/10.17504/protocol s.io. $5 \mathrm{kgg} 4 \mathrm{tw}$

Protocol Citation: Estelle Bigeard, Loïc Pillet, John Burns, Fabrice Not 2020. Collect of Collodarian (Rhizaria, Radiolaria) nuclei for genomic analyses. protocols.io https://dx.doi.org/10.17504/p rotocols. io. $5 \mathrm{kgg} 4 \mathrm{tw}$

License: This is an open access protocol distributed under the terms of the Creative Commons Attribution License, which permits unrestricted use, distribution, and reproduction in any medium, provided the original author and source are credited

Protocol status: Working We use this protocol and it's working

Created: Jul 17, 2019

Last Modified: Jun 15, 2020

PROTOCOL integer ID: 25960

\section{(3) Collect of Collodarian (Rhizaria, Radiolaria) nuclei for genomic analyses}

\author{
Estelle Bigeard ${ }^{1}$, Loïc Pillet²， John Burns²， Fabrice Not $^{3}$
}

${ }^{1}$ Station Biologique de Roscoff, France; ${ }^{2}$ AD2M, Station Biologique de Roscoff, CNRS, SU;

${ }^{3}$ CNRS \& Sorbonne University - Station Biologique de Roscoff

Ecology of Marine Plankton (ECOMAP) team - Roscoff

Roscoff Culture Collection

1 more workspace $\downarrow$

Estelle Bigeard

Station Biologique de Roscoff, France, UMR7144 CNRS Sorbonne...

\section{ABSTRACT}

Collodaria are ubiquitous and abundant marine radiolarian (Rhizaria) protists (Biard et al. 2015). They occur as large colonies (a few millimeters up to 3 meters long) or as solitary specimens. Collodarians are known to play an important role in oceanic food webs both as active predators and as hosts of intracellular endosymbiotic microalgae primarily belonging to the dinoflagellate genus Brandtodinium. Despite their important ecological roles, very little is known about their diversity and evolution. Taxonomic delineation of collodarians is challenging and only a few species have been genetically characterized.

Most Collodaria form colonies comprising tens to hundreds of individual radiolarian cells (i.e. central capsules) embedded in a gelatinous matrix. Each central capsule contains genomic DNA of the Collodaria host while the gelatinous matrix which also contains the DNA of prey and symbionts.

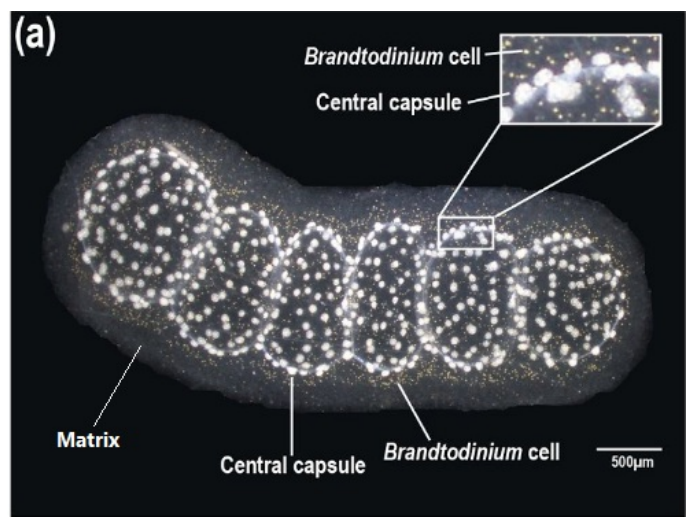

Figure 1: Cells (i.e. central capsules) are distributed in the matrix forming a well-defined compartment. Central capsules, appearing bright under the microscope, measure from 100 to $150 \mu \mathrm{m}$ in diameter. The dinoflagellate symbionts are enclosed in cytoplasmic structures, either localized within the gelatinous matrix or closely associated to the central capsules. (from Villar et al. 2018) 


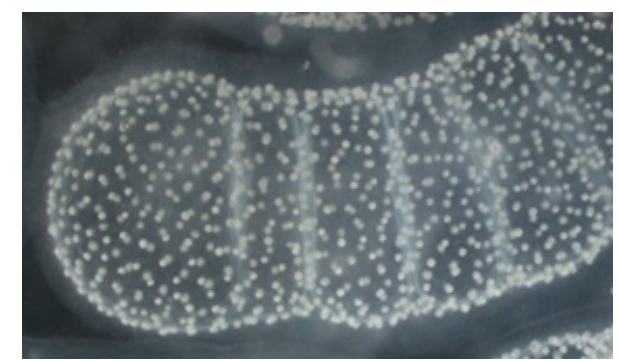

Figure 2a: 1 part of a Collodaria colony. Each cells is visible thanks to its central capsule (white dots) containing its nucleus. (PPictures IMPEKAB - E. Bigeard - VFR2016

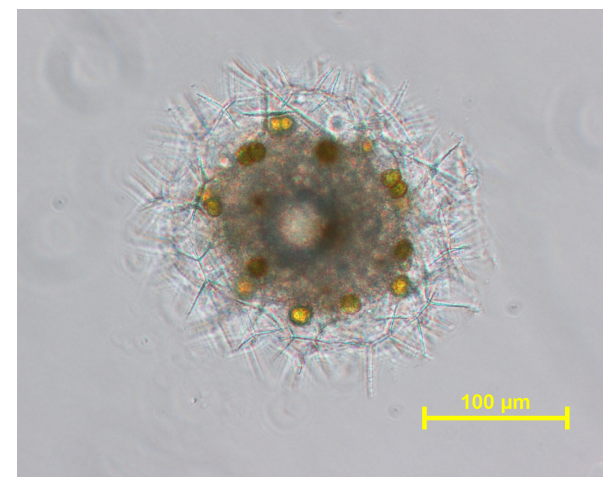

Figure 2b: Magnified view of a single central capsules with surrounding spicules (colorless) and symbionts (yellow). (c) Pictures - F. Not

Some species build a shell-like skeleton aroundtheir central capsule while others have siliceous spicules, similar to those in sponges, in the matrix, and some lack mineral structures altogether. Current taxonomic classification reveals several clades : Sphaerozoidae (skeleton-less but spicule-bearing), Collosphaeridae (mix of skeleton-bearing and skeleton-less taxa), Collophidiidae (skeleton-less). The family Thalassicollidae is composed exclusively of solitary species.

This protocol describes a method for isolating central capsules containing oly the genomic DNA of the collodarian host by removing prey and symbionts through targeted dissolution of the gelatinous matrix and removal all material outside of host central capsules.

\section{ATTACHMENTS}

2006 Lee et al.pdf Biard et al ISME2017.pdf Biard et al Protist2015.pdf Biard et al Nature2016.pdf 
protocol EB-BM-MO-016

Villar E, Dani V, Bigeard E, Linhart T, MendezSandin M, Bachy C, Six C, Lombard F, Sabourault C \& Not F (2018). Chloroplasts of symbiotic microalgae remain active during bleaching induced by thermal stress in Collodaria(Radiolaria) doi:10.1101/263053

Biard T, Bigeard E, Audic S, Poulain J, Gutierrez-Rodriguez A, Pesant S, Stemmann L \& Not F (2017). Biogeography and diversity of Collodaria (Radiolaria) in the global ocean. ISME Journal, doi:10.1038/ismej.2017.12

Biard T, Stemmann L, Picheral M, Mayot N, Vandromme P, Hause H, Gorsky G, Guidi L, Kiko R \& Not F (2016). In situ imaging reveals the biomass of giant protists in the global oceans. Nature, doi:10.1038/nature17652

Biard T., Pillet L., Decelle J., Poirier C., Suzuki N. \& Not F (2015). Towards an Integrative Morpho-molecular Classification of the Collodaria (Polycystinea, Radiolaria). Protist, doi:10.1016/j.protis.2015.05.002

Lee et al. (2007), Monitoring Repair of DNA Damage in Cell Lines and Human Peripheral Blood Mononuclear Cells, Anal Biochem. doi: 10.1016/j.ab.2007.03.016

\section{MATERIALS}

\section{Chemicals:}

Sucrose Ref S0389 - Sigma-Aldrich

Spermine Ref S3256 - Sigma-Aldrich

Spermidine Ref 85558 - Sigma-Aldrich

$\mathrm{NaCl}$ Ref 59888 - Sigma-Aldrich

$\mathrm{KCl}$ Ref P9333 - Sigma-Aldrich

Tris HCl Ref 15941 - Sigma-Aldrich

EDTA 0.5M pH8 Ref 03690 - Sigma-Aldrich

Igepal CA-630 Ref I8896 - Sigma-Aldrich

PBS Ref P3744-12PAK - Sigma-Aldrich

\section{Supplies:}

6wells - plate Ref CC7672-7506 - Starlab

40 $\mu$ sieve Ref 010198 - Dominique Dutscher

Petri dishes Ref 632191 - Dominique Dutscher

\section{Solutions}

Preparation of Solutions

1.1 Sucrose $3 \mathrm{M}(\mathrm{M}=342.3 \mathrm{~g} / \mathrm{mol})$

$112.96 \mathrm{~g}$ in $110 \mathrm{ml}$ water milliQ

Store at room temperature

1.2 Spermine $0.1 \mathrm{M}(\mathrm{M}=202.34 \mathrm{~g} / \mathrm{mol})$ 
Powder stored at $4^{\circ} \mathrm{C}$.

Weigh $40.5 \mathrm{mg}$ in a $15 \mathrm{ml}$ Falcon.

then add $2 \mathrm{ml}$ water milliQ.

Preparation instructions: This product is soluble in water $(50 \mathrm{mg} / \mathrm{ml})$, yielding a clear, colorless to light yellow solution. Storage / Stability: Store at $2-8^{\circ} \mathrm{C}$.

Solutions of spermine free base are readily oxidized. Solutions are most stable when prepared in degassed water and stored in frozen aliquots, under argon or nitrogen gas.

1.3 Spermidine $0.05 \mathrm{M}(\mathrm{M}=145.25 \mathrm{~g} / \mathrm{mol})$

Liquid stored at room temperature.

Weigh $87.15 \mathrm{mg}$ in a $15 \mathrm{ml}$ Falcon.

then add $12 \mathrm{ml}$ water milliQ.

Preparation instructions: Spermidine is soluble in water $(50 \mathrm{mg} / \mathrm{ml})$, ethanol, and ether.

Storage / Stability: Spermidine is very hygroscopic and air sensitive. A solution can be formed for storage by dissolving $1.45 \mathrm{~g}$ in $10 \mathrm{ml}$ of water and then sterilizing with a $0.22 \mu \mathrm{m}$ filter.

Store this solution as single-use aliquots at $-20^{\circ} \mathrm{C}$ for no longer than one month.

$1.44 \mathrm{M} \mathrm{NaCl}(\mathrm{M}=58.44 \mathrm{~g} / \mathrm{mol})$

Weigh $0.47 \mathrm{~g}$ of $\mathrm{NaCl}$.

Add $2 \mathrm{ml}$ of milliQ water.

Store at room temperature.

$1.5 \mathrm{KCl} 5 \mathrm{M}(\mathrm{M}=74.5513 / \mathrm{mol})$

Weigh $2.6 \mathrm{~g}$ of $\mathrm{KCl}$.

Add $7 \mathrm{ml}$ of milliQ water.

Store at room temperature.

1.6 Tris $\mathrm{HCl} 1 \mathrm{M} \mathrm{pH} 8(\mathrm{M}=157.60 / \mathrm{mol})$

Weigh $15.76 \mathrm{~g}$ of Tris $\mathrm{HCl}$.

Make up to $100 \mathrm{ml}$ of milliQ water.

Tamp to $\mathrm{pH} 8$.

Store at room temperature.

1.7 EDTA $0.5 \mathrm{M} \mathrm{pH} 8(\mathrm{M}=292.24 / \mathrm{mol})$

Weigh $15 \mathrm{~g}$ of EDTA.

Add $50 \mathrm{ml}$ of milliQ water.

Add $\mathrm{NaOH}$ pellets until a $\mathrm{pH}$ of 8 is reached.

QSP $100 \mathrm{ml}$ of water milliQ.

Filter on $0.2 \mu \mathrm{m}$.

Store at room temperature.

1.8 For $500 \mathrm{ml}$ of Lysis Buffer Solution

\begin{tabular}{||l|l|l|l|}
\hline Product & $\begin{array}{l}\text { Initial } \\
\text { concentr } \\
\text { ation }\end{array}$ & $\begin{array}{l}\text { Final } \\
\text { concentr } \\
\text { ation }\end{array}$ & volume \\
\hline
\end{tabular}




\begin{tabular}{|l|l|l|l|}
\hline Sucrose & $3 \mathrm{M}$ & $0.3 \mathrm{M}$ & $50 \mathrm{ml}$ \\
\hline $\mathbf{K C l}$ & $5 \mathrm{M}$ & $60 \mathrm{mM}$ & $6 \mathrm{ml}$ \\
\hline $\mathbf{N a C l}$ & $4 \mathrm{M}$ & $15 \mathrm{mM}$ & $1.875 \mathrm{ml}$ \\
\hline Tris HCl pH8 & $1 \mathrm{M}$ & $60 \mathrm{mM}$ & $30 \mathrm{ml}$ \\
\hline Spermidine & $0.05 \mathrm{M}$ & $0.5 \mathrm{mM}$ & $5 \mathrm{ml}$ \\
\hline Spermine & $0.1 \mathrm{M}$ & $0.15 \mathrm{mM}$ & $750 \mu \mathrm{l}$ \\
\hline EDTA & $0.5 \mathrm{M}$ & $2 \mathrm{mM}$ & $2 \mathrm{ml}$ \\
\hline $\begin{array}{l}\text { Igepal } \\
\text { CA-630 }\end{array}$ & & & $2.5 \mathrm{ml}$ \\
\hline $\begin{array}{l}\text { Water } \\
\text { milliQ }\end{array}$ & & & \begin{tabular}{c} 
Qsp \\
\hline
\end{tabular}
\end{tabular}

Table 1: Recipes for Lysis Buffer Solution

1.9 For $500 \mathrm{ml}$ of Wash Buffer solution

\begin{tabular}{|c|c|c|c|}
\hline $\begin{array}{l}\text { Prod } \\
\text { uct }\end{array}$ & $\begin{array}{l}\text { Initia } \\
\text { I } \\
\text { conc } \\
\text { entra } \\
\text { tion }\end{array}$ & $\begin{array}{l}\text { Final } \\
\text { conc } \\
\text { entra } \\
\text { tion }\end{array}$ & $\begin{array}{l}\text { volu } \\
\text { me }\end{array}$ \\
\hline $\begin{array}{l}\text { Sucr } \\
\text { ose }\end{array}$ & $3 \mathrm{M}$ & $0.3 \mathrm{M}$ & $50 \mathrm{ml}$ \\
\hline $\mathrm{KCl}$ & $5 \mathrm{M}$ & $\begin{array}{l}60 \mathrm{~m} \\
\mathrm{M}\end{array}$ & $6 \mathrm{ml}$ \\
\hline $\mathrm{NaCl}$ & $4 \mathrm{M}$ & $\begin{array}{l}15 \mathrm{~m} \\
M\end{array}$ & $\begin{array}{l}1.875 \\
\mathrm{ml}\end{array}$ \\
\hline $\begin{array}{l}\text { Tris } \\
\mathrm{HCl} \\
\text { pH8 }\end{array}$ & $1 \mathrm{M}$ & $\begin{array}{l}60 \mathrm{~m} \\
\mathrm{M}\end{array}$ & $30 \mathrm{ml}$ \\
\hline $\begin{array}{l}\text { Sper } \\
\text { midi } \\
\text { ne }\end{array}$ & $\begin{array}{l}0.05 \\
M\end{array}$ & $\begin{array}{l}0.5 \mathrm{~m} \\
\mathrm{M}\end{array}$ & $5 \mathrm{ml}$ \\
\hline $\begin{array}{l}\text { Sper } \\
\text { mine }\end{array}$ & $0.1 \mathrm{M}$ & $\begin{array}{l}0.15 \\
\mathrm{mM}\end{array}$ & $750 \mu \mathrm{l}$ \\
\hline EDTA & $0.5 \mathrm{M}$ & $2 \mathrm{mM}$ & $2 \mathrm{ml}$ \\
\hline
\end{tabular}




\begin{tabular}{|l|l|l|l|}
\hline $\begin{array}{l}\text { Wate } \\
\text { r } \\
\text { milli }\end{array}$ & & & Qsp \\
$\mathbf{Q}$ & & & $500 \mathrm{ml}$ \\
\hline
\end{tabular}

Table 2: Recipes for Wash Buffer Solution

\section{Selection of colonies}

2 Sort several colonies (maximum 20) according to their morphological type (segmented round shape, segmented straight form, non-segmented, purple color, blue dots, etc.) assuming it corresponds to a single species. Observe using a stereomicroscope and take pictures in wide field and zoom.
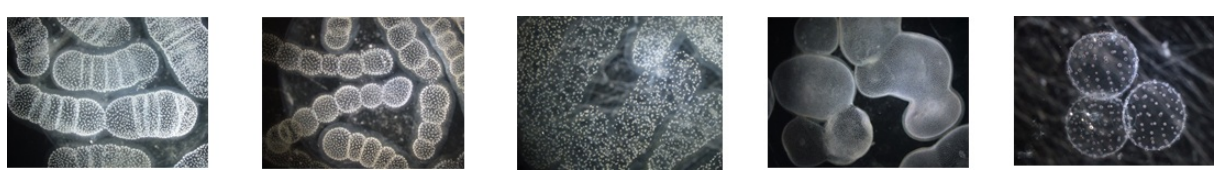

Figure 3 : Pictures from 5 different types of colladarians (Types A; B; C; D purple colonies \& E colonies with blue dots) (c) Pictures IMPEKAB - E. Bigeard - VFR2016

\section{Lysis of colonies}

In a 6-well plate, deposit $8 \mathrm{ml}$ of Lysis solution per well.

Add a $40 \mu \mathrm{m}$ diameter sieve previously rinsed with milliQ water per well. Place about 10 medium sized colonies $(1.5-2 \mathrm{~cm})$ per sieve. Incubate for 30 minutes at room temperature.

Take a sieve from a well, place it in a $90 \mathrm{~mm}$ diameter petri dish containing Lysis solution.

Tap the sieve and shake circles with the sieve in the BP.

Repeat several times until the matrix breaks up and is released from the sieve (about 3 minutes).

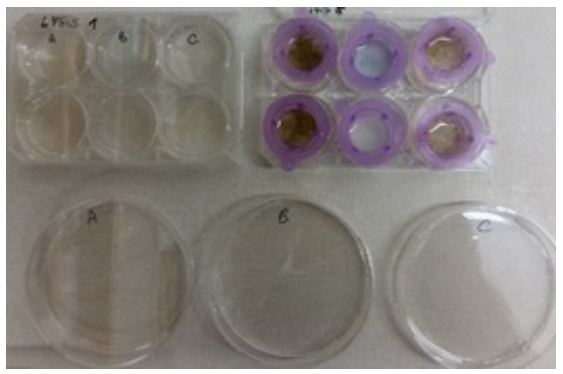

Figure 4: Plates containing lysis buffer and sieves with colonies and BP containing wash buffer - @Pictures IMPEKAB - E. Bigeard - VFR2016

For purple colonies and those with blue dots, just one lysis will suffice. For other types, perform with a second lysis as below. In a 6-well plate, deposit $8 \mathrm{ml}$ of Lysis solution per well. Place the sieve containing the colonies at the beginning of lysis. Incubate again for 30 minutes at room temperature.

\section{Washing of central capsules}


4 Remove the sieve from the well and place it in the petri dish containing Wash solution.

Tap the sieve and shake circles with the sieve in the BP.

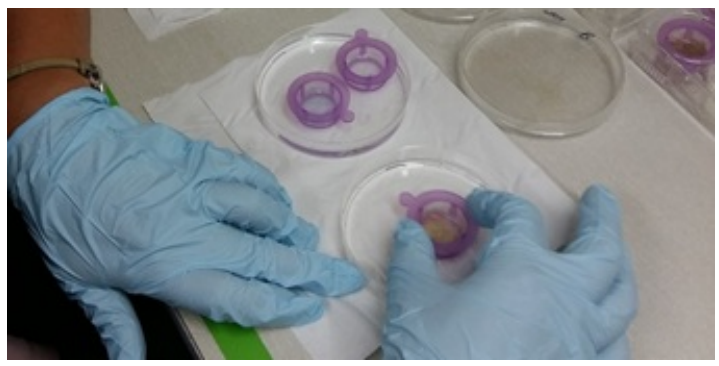

Figure 5 : Washing of collodarian central capsules - @Pictures IMPEKAB - E. Bigeard - VFR2016

Washing of nuclei present in the sieve.

Repeat several times until the matrix is completely removed.

Observe and control with a binocular loupe (capsule size with respect to the pores, cleanliness of the sample, etc.).

Take pictures If OK.

\section{Rinsing \& Concentration of nuclei}

Rinse the capsules in $1 \times$ PBS solution or in $0.2 \mu \mathrm{m}$ filtered and autoclaved seawater in a $90 \mathrm{~mm}$ diameter BP.

Remove the capsules from the sieve by rinsing it with $0.2 \mu \mathrm{m}$ filtered seawater or $1 \mathrm{x}$ PBS solution.

Place the capsules in a $1.5 \mathrm{ml}$ microtube (or $2 \mathrm{ml}$ microtube if necessary).

Centrifuge at 1000 rcf 10 minutes.

Remove the supernatant.

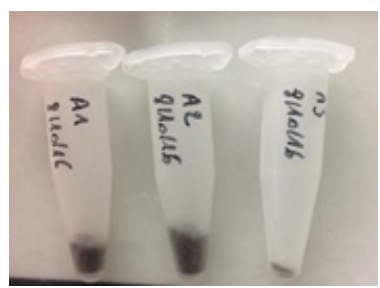

Figure 6: Pellet of central capsules - @Pictures IMPEKAB - E. Bigeard - VFR2016

Flash freezer.

Storage at $-80^{\circ} \mathrm{C}$.

If using of sea water in the above steps, it is better to rinse with PBS before the DNA extraction to remove salt:

Rinse with $1 x$ PBS solution by depositing $500 \mu$ l of PBS solution into the microtube.

Tap gently.

Centrifuge at 1000 rccf 10 minutes.

Remove the supernatant.

Repeat once if necessary.

\section{Analyses}

The DNA extraction method will be published under a separate protocols.io (in collaboration with Genoscope). 
